\title{
Biofloc Technology in Shrimp Farming
}

\author{
Shiva kumar Magada* \\ Professor of Aquatic Biology, College of Fisheries, India
}

Submission: January 07, 2019; Published: February 22, 2019

Corresponding author: Shiva kumar Magada, Professor of Aquatic Biology, College of Fisheries, Mangalore, India

\section{Opinion}

Most of the efforts in research is to understand the nature and the truth. Even in the field of aquaculture many such efforts led to blue revolution in the world. The global fish production is 158 million tonnes $(\mathrm{mt})$ of which $66 \mathrm{mt}$ come from freshwater. India is producing $10.07 \mathrm{mt}$ of fish and $6.0 \mathrm{mt}$ is contributed from freshwater aquaculture. India is earning 38000 crores by exporting 10.5 lakh tons of fish and fishery products. Of which 20,000 crores contributed by export of Litopenaeus Vannamei -the white shrimp. After a major disease outbreak in tiger shrimp farming, many farmers started culturing the white shrimp which is native to Latin America.

\section{Why Biofloc Technology (BFT)?}

Biofloc technology is a technique of flocculating heterotrophic food in aquaculture ponds through balancing carbon and nitrogen in the system. Biofloc is a consortium of algae, bacteria (Both useful and pathogenic), saprophytes and such other microscopic plankton. About $60 \%$ of the microscopic natural food in the pond is less than 60 micron which even fishes cannot feed on them. When they are flocculated, they are available for fishes and it forms a very nutritive food with 12 $25 \%$ protein, $15-32 \%$ dry matter and $30-60 \%$ carbohydrates on dry weigh matter. This flocculation enhances water quality and reduces the requirement of supplementary diet. BFT is all about managing C:N ratio (Carbon and Nitrogen ratio) and ammonia. If this ratio is maintained more than 10 in aquaculture ponds, the productivity increases significantly. In other words, it is recycling of nutrients and nutrients recovery in the form of biomass. The nitrogen is available in plenty in any aquafarm. It comes from feed waste, faecal matter and dead and decayed material in the pond but carbon is a limiting factor. Hence, it has to be supplied from the outside. In many countries, farmers use molasses. These days' molasses is in high demand and it goes for alcohol production. As alternatives joggery or sugar can be used.

\section{Agent of Change}

Mr Sunny D'Souja, who has worked in different fields of aquaculture, started practicing this BFT in his farm. He has 16000 $\mathrm{m}^{2}$ (4 acres) of land at Haleyangadi-20 km away from Mangalore, Karnataka, India. He has constructed 10 ponds of different sizes with a water spread area of $13000 \mathrm{~m} 2$ and they lined with 160 gsm, 250-400 micron, UV treated plastics. The average depth of pond is $1.5 \mathrm{~m}$. He uses the water from nearby creek where the salinity ranges from 8-35 ppt in a year. It is a recycling system, where there is no water exchange unless there is a heavy algal bloom and high evaporation. He uses $25 \mathrm{HP}$ capacity air blowers $24 \mathrm{X} 7$ and air is passed through special air stones of $1.5 \mathrm{~m}$ and 4-inch diameter which has the capacity of dispersing the air bubbles as small as $0.3 \mathrm{~mm}$. Air stones are positioned at the bottom as many 100/acre. (See the farm with this link https:// www.facebook.com/manu.tvm/videos/469886750070736/) (Figure 1).

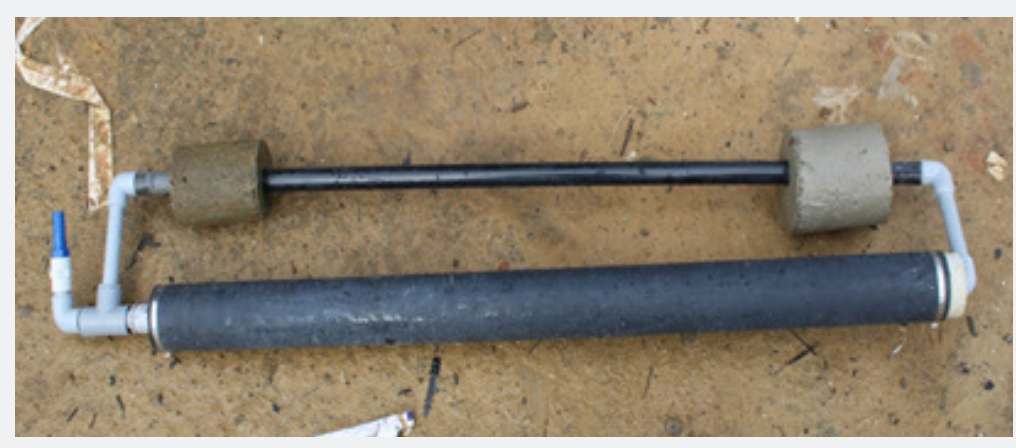

Figure 1: Airstone with concrete sinks having $0.3 \mathrm{~mm}$ air hole, $1.5 \mathrm{~m}$ length and 3-inch diameter. 
He stocks the ponds with L. Vannamei PL @ 250/m2 and used commercial feeds with high protein. With support of check trays, feeding is ad libitum. After 60 days, stock is thinned out by culling the larger ones. Later every 15 days or depending on the demand and price, stock is marketed. In last crop, in about 110 day of culture period, he has harvested $17 \mathrm{t} /$ acre and sold for Rs. $310 / \mathrm{kg}$ of shrimp with 50 count. He cost of production is about Rs. 130-150/kg. The gross revenue was Rs. 55 lakhs in 3.25 acres and earned net profit of 35 lakhs.

\section{Success Breeds Success}

The average L. vannamei production in India is about 8-10 t/ ha, but Mr Sunny D' Souja has harvested 35-40 t/ha. The greatest point to be noted by reading this report is Mr Sunny D'Souja, despite possibility of increasing competitors in his vicinity, he reveals all the business secrets and he wants many more people to take up this business. Since the demand for shrimp is huge, many more can harness the opportunity along Karnataka coast. ICAR-Krishi Vigyan Kendra, Dakshina Kannada will play a facilitative role in up-scaling this project along the Karnataka coast. (Figures $2 \& 3$ )

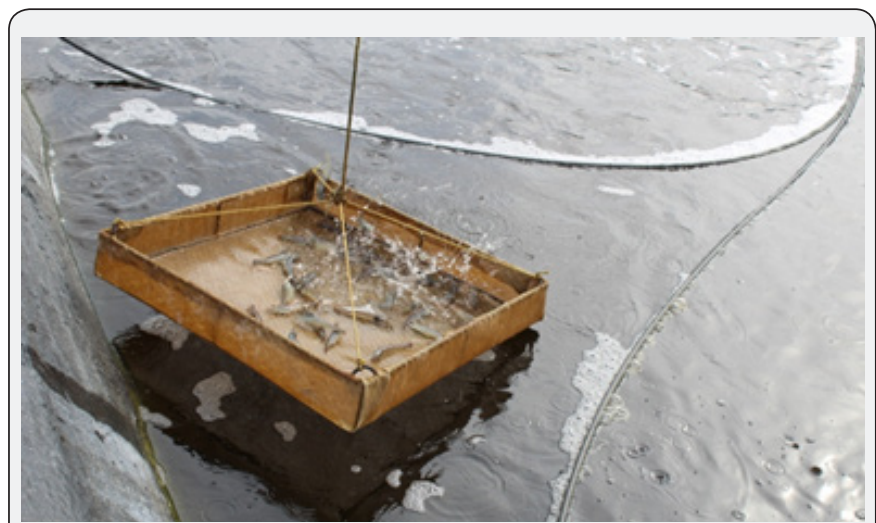

Figure 2: Check Tray has become harvesting tray.

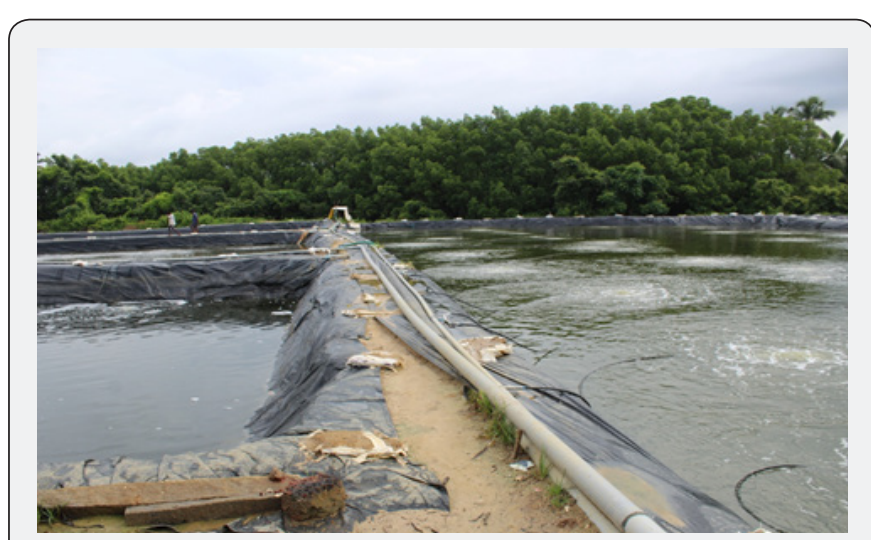

Figure 3: Ponds with lining and aeration.

\section{Save Power}

This BFT requires continuous power supply to support the aeration. In exigency, without aeration, the systems can be managed for 3-4 h but not beyond that. Normally, to produce $400-500 \mathrm{~kg}$ of biomass, it requires $1 \mathrm{HP}$, but in BFT system it is possible to produce $1000-1150 \mathrm{~kg} / \mathrm{HP}$. This reduces the cost of production (CoP) drastically. Despite regular power supply, there must be backup diesel operated generator of required capacity. Since BFT saves energy over $50 \%$, this is most often referred as "Ecofriendly"

\section{Environment Friendly}

Apart from saving power, the BFT is truly environmentally friendly system. The major issue in shrimp farming is secondary salinization of agriculture and other adjacent lands. This is common issue due to seepage and percolation. Since BFT is recycling system, there is least water exchange. HDPE pond lining completely avoids the seepage and percolation. The organic load of the ponds is efficiently recycled, there is no issue of contaminating the nearby water sources.

\section{You love Economics}

The average vannamei shrimp production is about $8-10 \mathrm{t} /$ ha. With BFT, the potential production goes over $40 \mathrm{t} / \mathrm{ha}$. The cost of production ranges between Rs. $130-160 / \mathrm{kg}$. The average gate value of vannamei with a 40 count $/ \mathrm{kg}$ is Rs. $300+/ \mathrm{kg}$. Net profit over $100 \%$ in $110-120$ days is like growing gold in the water. Comfortably, one can take two crops per year. Because of the scale of economy, profits are high. Though we have least control over market price, with better management the CoP can be reduced, and profit margin can be increased.

\section{The overall Advantages of BFT are}

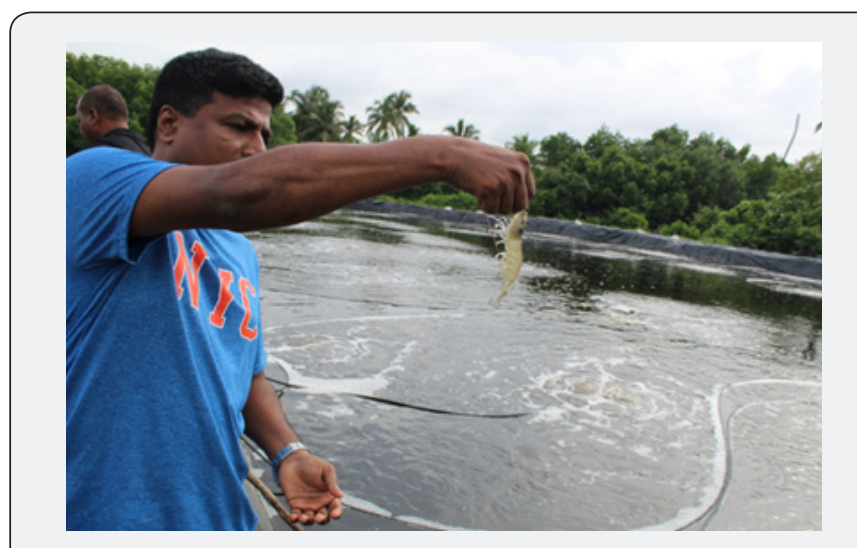

Figure 4: Healthy Litopenaeus vannamei.

a. No water exchange, only recycling

b. Stocking density can be increased

c. High productivity

d. Less power consumption

e. Sustainable

f. Environmentally friendly 
g. Better FCR

h. Low disease incidence

i. Uniform growth

j. $\quad$ High income (Figure 4)
Disadvantages

a. High energy input

b. Power failure is critical. Backup power supply is must

c. UV treated HDPE lining is required

d. Non-availability of skilled manpower to operate BFT

Your next submission with Juniper Publishers will reach you the below assets

- Quality Editorial service

- Swift Peer Review

- Reprints availability

- E-prints Service

- Manuscript Podcast for convenient understanding

- Global attainment for your research

- Manuscript accessibility in different formats ( Pdf, E-pub, Full Text, Audio)

- Unceasing customer service

Track the below URL for one-step submission https://juniperpublishers.com/online-submission.php 